\title{
EDITORIAL
}

\section{Schizophrenia, the forgotten disorder: the scenario in Brazil}

\author{
Gabriela Matos, ${ }^{1}$ Francisco B. Guarniero, ${ }^{1}$ Jaime E. Hallak, ${ }^{2}$ Rodrigo A. Bressan ${ }^{3}$ \\ ${ }^{1}$ Janssen-Cilag Farmacêutica, São Paulo, SP, Brazil. ${ }^{2}$ Department of Neurosciences and Behavior, Ribeirão Preto Medical School, \\ Universidade de São Paulo (USP), Ribeirão Preto, SP, Brazil. ${ }^{3}$ Department of Psychiatry, Universidade Federal de São Paulo - Escola \\ Paulista de Medicina (UNIFESP-EPM), São Paulo, SP, Brazil.
}

Schizophrenia is a severe mental disorder characterized by significant disruptions in thinking, perception, cognition, and emotions. ${ }^{1}$ It has been considered one of the five leading causes of disability-adjusted life years (DALYs) in mental and behavioral disorders, which accounted for $7.4 \%$ of total worldwide DALYs from 1990 to $2010 .^{2}$ The burden of schizophrenia is heavy and complex, and involves family burden, poor treatment response, reductions in quality of life, hospitalizations, loss of productivity, and high mortality. In light of the abovementioned aspects, early diagnosis and effective treatment to decrease morbidity are imperative.

World Mental Health Day will be celebrated on October 10 , and its theme for 2015 is "dignity in mental health." Raising awareness of mental health is a priority for the World Health Organization (WHO), through actions that include providing guidance about human rights, treatment, and education, as well as other initiatives. A recent Brazilian Congressional bill (Projeto de Lei $n^{\circ}$ 588/2015), ${ }^{3}$ elaborated in partnership between Representative Mara Gabrili and the Schizophrenia Program at Universidade Federal de São Paulo (UNIFESP), recommended coverage for people with psychosocial disabilities in a social inclusion program, designed to integrate this group into the job market in the state of São Paulo, Brazil. It is exciting to know that some of the WHO goals regarding mental illness are being accomplished in Brazil; however, what is the real picture of schizophrenia in our country?

Few studies have examined the prevalence of schizophrenia in Brazil, and the majority of these were conducted more than 10 years ago. Based on these studies, ${ }^{4-7}$ the population-wide prevalence of schizophrenia in Brazil is estimated at about $0.8 \%$. This would correspond to more than 1.6 million people in Brazil currently living with schizophrenia. $^{8}$ In this context, one study conducted in Brazil showed that the majority of patients with schizophrenia $(81.5 \%)$ were allocated to the public health sector and $71.0 \%$ of them did not receive regular treatment. ${ }^{6}$ According to DATASUS, the administrative database for the Brazilian Unified Health System, in 2011 alone, 65,126 people who experienced a schizophrenia relapse were assisted in the public system: 44,453 were admitted to a hospital for at least one day, 20,531 were assisted

Correspondence: Jaime E. Hallak, Ribeirão Preto Medical School, Universidade de São Paulo (USP), Av. Bandeirantes, 3900, Hospital das Clínicas, $3^{\circ}$ andar, CEP 14048-900, Ribeirão Preto, SP, Brazil. E-mail: jhallak@fmrp.usp.br intensively in the outpatient setting at psychosocial care centers (CAPS), and 142 individuals received intensive same-day hospital care. ${ }^{8}$

This figure is very alarming; more than 900,000 of the 1.6 million individuals with schizophrenia in the public system do not receive minimally satisfactory treatment. Where are these improperly treated individuals? The answer to this question seems complex, and, indeed, we do not know. Some reach emergency rooms, receive treatment for psychotic episodes, and are then discharged. How many of these individuals receive treatment for relapse prevention? Except for those who enter the few schizophrenia programs available in some outpatient settings, the majority of these individuals do not follow treatment and become lost in the health system.

It is worth noting that relapse rates can reach up to $80.0 \%$ after 12 months without pharmacological treatment for patients after the first psychotic episode. ${ }^{9}$ Indeed, the probability of relapse is significantly higher in those partially adherent to medication, even with effective treatment in the years preceding interruption. ${ }^{10}$ It is known that roughly half of all individuals with schizophrenia in Brazil do not adhere to antipsychotic medication. ${ }^{11}$ In this scenario, a powerful tool for managing medication nonadherence is the use of long-acting injectable antipsychotics, which may result in better control of adherence, thus reducing relapse rates. The adoption of this clinical practice is highly recommended for patients who do not adhere to antipsychotic treatment, and second-generation injectables are currently suggested as maintenance treatment, even after a recent episode. ${ }^{12,13}$

The distance between the "optimal" and the "real" scenario should be at least somewhat reduced. We recognize that the challenge is huge, as there are many barriers to overcome, from stigma to cultural and demographic boundaries. However, we should not be passive in our response to this situation, waiting for patients to knock on our doors asking for assistance. Simple attitudes, such as active case search, psychoeducational support groups for families and patients, welltrained psychiatrists, and multidisciplinary approaches, can support a better prognosis for these patients and change current outcomes in schizophrenia.

\section{Disclosure}

GP and FBG are Janssen-Cilag employees. The other authors report no conflicts of interest. 


\section{References}

1 World Health Organization (WHO). Schizophrenia - Fact sheet $n^{\circ}$ 397; [Internet]. 2014 [cited 2015 Aug 17]. http://www.who.int/mediacentre/factsheets/fs397/en/.

2 Murray CJ, Vos T, Lozano R, Naghavi M, Flaxman AD, Michaud C, et al. Disability-adjusted life years (DALYs) for 291 diseases and injuries in 21 regions, 1990-2010: a systematic analysis for the Global Burden of Disease Study 2010. Lancet. 2012;380:2197-223.

3 Assembleia Legislativa do Estado de São Paulo. Projeto de lei $n^{\circ} 588 /$ 2015. Dispõe sobre a inclusão de pessoas com deficiência psicossocial no Programa de Apoio è Pessoa com Deficiência (PADEF) promovido pelo Poder Executivo no âmbito do Estado, através da Secretaria Estadual do Emprego e Relações do Trabalho [Internet]. 2015 May 01 [cited 2015 Oct 05]. http://www.al.sp.gov.br/propositura/?id=1255523.

4 Almeida-Filho N, Mari JJ, Coutinho E, França JF, Fernandes J, Andreoli SB, et al. Brazilian multicentric study of psychiatric morbidity. Methodological features and prevalence estimates. $\mathrm{Br} \mathrm{J}$ Psychiatry. 1997;171:524-9.

5 Andrade LHSG, Lólio CA, Gentil Filho V, Laurenti R. Epidemiologia dos transtornos mentais em uma area definida de captação da cidade de São Paulo, Brasil. Rev Psiquiatr Clin (São Paulo). 1999;26:257-61.

6 Leitão RJ, Ferraz MB, Chaves AC, Mari JJ. Cost of schizophrenia: direct costs and use of resources in the State of São Paulo. Rev Saude Publica. 2006;40:304-9.
7 Theme-Filha MM, Szwarcwald CL, Souza-Junior PR. Socio-demographic characteristics, treatment coverage, and self-rated health of individuals who reported six chronic diseases in Brazil, 2003. Cad Saude Publica. 2005;21:S43-S53.

8 Kiusiang TT, Pezzullo L, Violin BB, Sardi P, Delatorre RM, Pititto L, et al. The potential benefits of long-acting atypical antipsychotic injections in preventing relapse in Brazilln: 17th Annual European Congress; 8-12 November 2014; Amsterdam RAI.

9 Emsley R, Chiliza B, Asmal L, Harvey BH. The nature of relapse in schizophrenia. BMC Psychiatry. 2013;13:50-50.

10 Emsley R, Oosthuizen PP, Koen L, Niehaus DJ, Martinez G. Symptom recurrence following intermittent treatment in first-episode schizophrenia successfully treated for 2 years: a 3-year open-label clinical study. J Clin Psychiatry. 2012;73:e541-7.

11 Rosa MA, Marcolin MA, Elkis H. Evaluation of the factors interfering with drug treatment compliance among Brazilian patients with schizophrenia. Rev Bras Psiquiatr. 2005;27:178-84.

12 Llorca PM, Abbar M, Courtet P, Guillaume S, Lancrenon S, Samalin L. Guidelines for the use and management of long-acting injectable antipsychotics in serious mental illness. BMC Psychiatry. 2013;13: 340.

13 Subotnik KL, Casaus LR, Ventura J, Luo JS, Hellemann GS, Gretchen-Doorly D, et al. Long-acting injectable risperidone for relapse prevention and control of breakthrough symptoms after a recent first episode of schizophrenia: a randomized clinical trial. JAMA Psychiatry. 2015;72:822-9. 